\title{
THE EVALUATION OF SHORT AND LONG TERM ADMINISTRATION OF DRUGS IMPROVING LIFE EXPECTANCY IN PATIENTS WITH MYOCARDIAL INFARCTION IN A HUNGARIAN COUNTY HOSPITAL
}

\author{
László Márk, Győző Dani, Erzsébet Nagy, Ferenc Erdei, András Katona \\ Department of Internal Medicine II - Cardiology, Pándy Kálmán Békés County Hospital, Gyula, Hungary
}

\section{SUMMARY}

Objective: The patients after myocardial infarction could hope for a significant improvement in their life expectancy when complying with the principles of the secondary prevention. Today there is no doubt that the administration of ACE-inhibitors, beta-blockers, aspirin and statins decrease mortality in these patients. Although the clinicians are aware of the guidelines of Evidence Based Medicine, international and Hungarian surveys show that in their everyday application there is still much to improve.

Patients and methods: The authors studied the therapy of 200 consecutive patients ( 115 men and 85 women) who suffered from acute myocardial infarction (either STAMI or NSTAMI) in 1999-2000 at the discharge from their internal medicine department with cardiological profile and 6 months later during outpatient check-up. Having these therapeutic data a special emphasise was given to the same group of drugs and their administration was investigated in patients suffering from acute coronary syndrome with elevated troponin-T levels in the year 2002.

Results: In the study of years 1999-2000 at the discharge 175 of 200 patients received ACE-inhibitor (87\%), 121 (60\%) beta-blocker, 180 $(90 \%)$ antiplatelet and $102(51 \%)$ statin therapy. At the time of the control performed 6 months later $85 \%$ of the patients were on ACE-inhibitor, $88 \%$ on beta-blocker, $77 \%$ on aspirin and $47 \%$ on statin therapy. In this high risk population during the 6 months control the LDL-cholesterol goal of $2.5 \mathrm{mmol} / \mathrm{l}$ was attained in the $17 \%$ of patients. In the survey performed in 2002 the use of beta-receptor blocker increased to $85 \%$, antiplatelet drug and statin administration to $95 \%$ and $57 \%$, respectively.

Conclusions: Although the administration of drugs improving life expectancy in the authors' department is comparable with the published Hungarian and international data, effort to the widespread application of the ever growing principles of the Evidence Based Medicine and continuous self-control are essential.

Key words: acute myocardial infarction, secondary prevention, statins, antiplatelet therapy, Evidence Based Medicine

Address for correspondence: L. Márk, $2^{\text {nd }}$ Department of Internal Medicine-Cardiology, Pándy Kálmán Békés County Hospital, Semmelweis u. 1., P.O. Box 46. H-5700 Gyula, Hungary. E-mail: mark@pandy.hu

\section{INTRODUCTION}

The mortality related to coronary heart disease is the leading cause of death in the industrialised countries, like Hungary and Czech Republic as well $(1,2)$. In patients having survived an acute myocardial infarction (AMI) the incidence of cardiovascular risk factors is higher than in normal population (3), and the probability of a new cardiovascular event is very high. $25 \%$ of the postMI men and $38 \%$ of women die in the first year (4). The life expectancy of these patients could be improved by their adherence to principles of prevention. Life-style change, risk factor interventions, together with appropriate drug therapy can reduce significantly the cardiovascular morbidity and mortality (5). There are a lot of large, prospective, randomized studies proving the very favourable effect of antiplatelet, beta-blocker, ACE-inhibitor and statin therapy. The administration of aspirin is the most cost-effective in the improvement of life expectancy in postAMI patients $(6,7)$, and betablockers could reduce the incidence of sudden cardiac death and reinfarction by $25 \%(8,9,10)$. The use of ACE-inhibitors reduces the mortality by the regulation of neuroendocrine activation and remodeling inhibition $(11,12,13)$. The favourable effect of the lipid lowering therapy is at least as great as the use of other secondary prevention's drugs (14). The 4S, CARE, LIPID and GREACE studies have shown a significant total and cardiovascular mortality reducing effect of statins in postAMI patients with high risk and considerably or slightly elevated serum cholesterol level $(15,16$, 17, 18). The administration of this group of drugs is recommended after the initiation of standard acute therapy in every patient with AMI having no contraindication.

Although the clinicians are aware of the guidelines of Evidence Based Medicine, international and Hungarian surveys show that in their everyday application there is much to improve. The Cardiovascular Hospitalization Atherosclerosis Management Program in Los Angeles proved that the beginning of application of secondary treatment options before discharge, during the hospital stay, determines positively the number of appropriately treated patients and the patients' compliance for a long time. Due to the education of nurses and physicians the use of lipid lowering drugs at the time of discharge increased from $6 \%$ to $86 \%$, and that of aspirin, beta-blockers and ACE-inhibitors changed favourable as well (19). 
The EUROASPIRE I study was conducted between 1991 and 1995 in patients after AMI, acute coronary syndrome or percutaneous coronary intervention. 6 months after the event $1 / 4$ of patients were smokers, the cholesterol level was higher than 5.2 $\mathrm{mmol} / \mathrm{l}$ at $3 / 4$ of them, and only $30 \%$ were taking beta-blocker and $75 \%$ aspirin (20). According to the results of EUROASPIRE II, 4-5 years later, the administration of beta-blockers increased to $63 \%$, that of aspirin to $86 \%$ (21). In the Hungarian centers of this study, the proportion of patients taking aspirin and lipid lowering drugs was lower; the use of ACE-inhibitors and beta-blockers was higher (22).

In the present study the frequency of administration of these drugs was investigated in patients treated because of AMI in the Coronary Care Unit of our internal medicine department with cardiological profile at the time of discharge and at the 6th months control examination. The accuracy of our recommendations with the former results in mind was evaluated.

\section{PATIENTS AND METHODS}

Beginning from 1 January 1999 the data of 200 consecutive patients, discharged from our department with AMI were analyzed retrospectively. The diagnosis of AMI (either ST segment elevation or non ST segment elevation) was established (based) on the clinical features, ECG and enzyme analysis. Based on the final reports' data the risk factors, lipid results and the medicines prescribed for the patients at the discharge time were analyzed, focusing on platelet inhibitors, ACE-inhibitors, beta-blockers and lipid lowering drugs.

90 patients had returned half year later for a control examination at our outpatient department and the administration of medicines suggested at the time of their hospital discharge was checked.

With the full knowledge of the previous results we looked over the medication of patients (with the same diagnosis) who were treated at our ward between 1 January-31 December 2002. We examined how the results of study between 1999-2000 influenced the subsequent drug recommendations. Our final results about the application of guidelines were compared with data of similar Hungarian and international studies.

\section{RESULTS}

After 1 January 1999 there were among 200 consecutive patients having survived acute myocardial infarction $115(57.5 \%)$ men (mean age $64.7 \pm 10.6$ years), and $85(42.5 \%)$ women (mean age $68.9 \pm 10.9$ years). 170 (85\%, 100 men and 70 women) were admitted with ST segment elevation AMI (67 of them, 39.4\% received thrombolytic therapy), 30 (15\%, 15 men and 15 women) with non ST segment elevation AMI. $16 \%$ of the examined patients had AMI previously, 59\% had hypertension, 25\% suffered from diabetes, $12 \%$ had stroke and $15 \%$ had peripheral vascular disease in their history. $77 \%$ were overweight (BMI $\left.>25 \mathrm{~kg} / \mathrm{m}^{2}\right)$, $62.4 \%$ were smoker. Although the analysis of lipid parameters was performed in the acute phase of AMI, when secondary to the acute phase reaction the results are inaccurate, in $75 \%$ of the patients the cholesterol level was higher than $5.2 \mathrm{mmol} / \mathrm{l}$. The average cholesterol level proved to be $5.59 \pm 0.97 \mathrm{mmol} / 1$, the LDL-cholesterol $3.62 \pm 0.89$, the triacylglycerols $1.76 \pm 0.73$, and the HDL-cholesterol $1.13 \pm 0.23 \mathrm{mmol} / \mathrm{l}$.
At the time of hospital discharge $90 \%$ of patients were taking aspirin, $61 \%$ beta-blockers, $88 \%$ ACE-inhibitors and $51 \%$ lipid lowering drugs. Comparing our results with data of the Euro Heart Survey 2002 (23) it is apparent that treatment suggestions for antiplatelet drugs and ACE inhibitors occurred more frequently ( $90 \%$ vs. $86 \%$ and $88 \%$ vs. $57 \%)$ than that for $\beta$-receptor blockers ( $61 \%$ vs. $75 \%)$. The frequency of lipid lowering treatment was similar (51\% vs. 53\%). Comparing our results with the data of Szeged Medical Center (24) we could establish, that the rate of aspirin and $\beta$-receptor-blockers use was lower ( $90 \%$ vs. $95 \%$ and $61 \%$ vs. $79 \%$ ), the administration of ACE-inhibitors and mainly that of lipid lowering drugs occurred more often. ( $88 \%$ vs. $82 \%$ and $51 \%$ vs. $39 \%$ ) (Fig. 1 ).

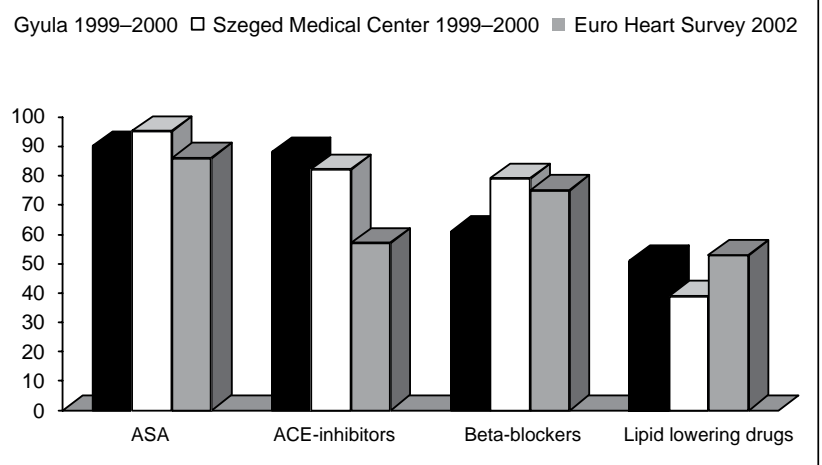

Fig. 1. The administration rate of the drugs improving life expectancy in the authors'department, Szeged Medical Center and Euro Heart Survey at the hospital discharge.

90 of the 200 examined patients appeared for the half year cardiological control. This time $77 \%$ of the patients were recommended to take aspirin, $88 \%$ beta-blockers, $86 \%$ ACEinhibitors, and 48\% lipid lowering drugs. Comparing our data with that EUROASPIRE II we gave ACE-inhibitors (86\% vs. $57 \%$ ), aspirin (77\% vs. $75 \%$ ), beta-receptor-blockers (88\% vs. $84 \%$ ) more frequently while the administration of lipid lowering drugs was similar (48\% vs. 51\%). (Fig. 2). Concerning the achievement of target lipid levels, in this high risk population the LDL-cholesterol of $2.5 \mathrm{mmol} / 1$ was reached only in $17 \%$ of the patients at the $6^{\text {th }}$ months control. The target $4.5 \mathrm{mmol} / 1$ total cholesterol level was attained in $21 \%$.

Being aware of the results of the study from 1999 and 2000 we examined the medication of the 165 patients having survived AMI, treated in 2002, at hospital discharge. We found that the previous, extremely low administration rate of beta-blockers increased significantly (61\% vs. $89 \%$ ). The same held true for aspirin and lipid lowering drugs, which increased only slightly from $90 \%$ vs. $96 \%$ and $51 \%$ vs. $57 \%$, respectively. There was no change in the usage of the ACE-inhibitors (88\% vs. 88\%) (Fig. 3).

\section{DISCUSSION}

Patients having survived AMI have a 5-7 times higher risk of the subsequent cardiovascular events than the population without known coronary disease. A large amount of great, prospective studies proved that in these high risk groups the proper treatment, the lifestyle change, the risk factor control could reduce the cardiovascular 
Gyula 1999-2000 DEUROASPIRE II Hungarian data 1999-2000

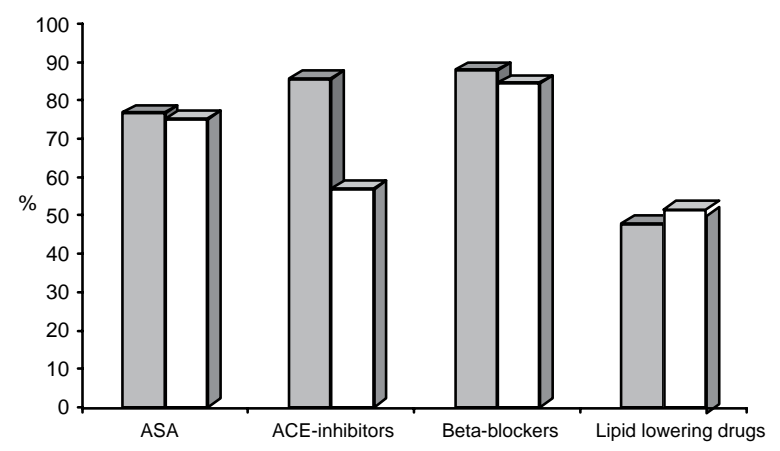

Fig. 2. The administration rate of the drugs improving life expectancy in the authors' outpatient department and Hungarian centeres of EUROASPIRE II at the half year control.

morbidity and mortality rate. Nowadays in Hungary about 25,000 $\mathrm{AMI} /$ year occur making thus in this group of patients the application of principles of secondary prevention the most cost-effective measure. However, in spite of the continually increasing strictness of the guidelines and decreasing target levels international and Hungarian experiences show that abundant unexploited reserves are available in the treatment of AMI. Doctors and special trained staff should collaborate closely with the patients, providing them information about keeping diet, physical exercises and healthy way of life and changing smoking habits. Vale et al. in their randomised controlled trial in patients with coronary heart disease in Australia found that the

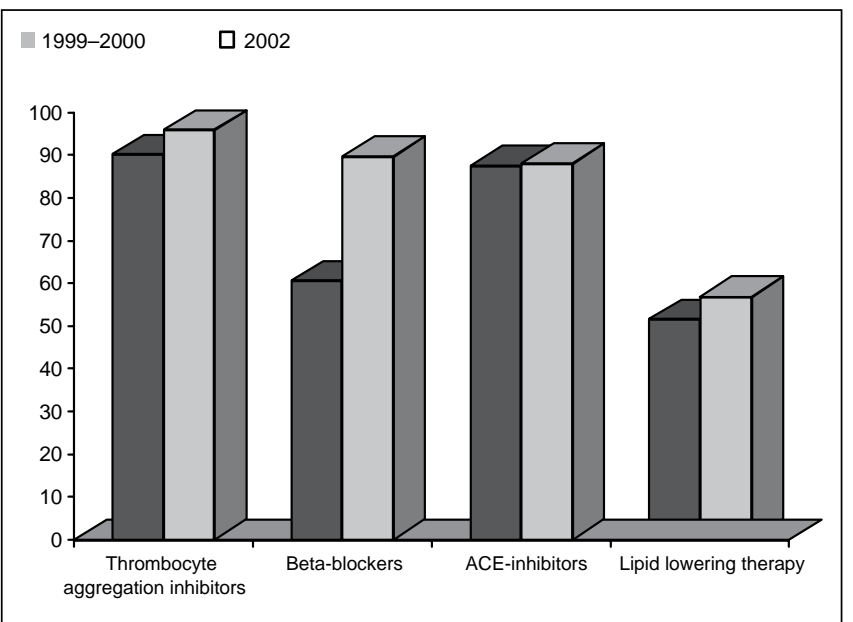

Fig. 3. The administration rate of the drugs improving life expectancy in the authors' department at the hospital discharge in 1999-2000 and in 2002.

coaching intervention was a good method to reduce the treatment gap in applying evidence based medicine to the "real world" (25). In the 4 years time between EUROASPIRE I and II no essential change in the risk factor's frequency were experienced while improvements were observed in the drug therapy $(20,21,22,26)$. During this period of time the application of aspirin and beta-blockers increased by $11 \%$ and $33 \%$, respectively. Unfortunately, the administration of statins is lower in Hungarian surveys than in international ones.

Nowadays, in the time of quality assurance we believe that it is not enough to know the latest principles of the Evidence Based Medicine, but we should apply them in the every day clinical practice as well. Pearson et al. found a significant difference between the knowledge of the principles of lipid lowering treatment and the target levels achieved (27). That's why we have set ourselves an aim to review our clinical practice and check whether it corresponds with other published results. $90 \%$ of our patients having survived AMI in 1999 and 2000 were given antiplatelet therapy, $88 \%$ got ACE-inhibitor, $61 \% \beta$-receptor-blocker and $51 \%$ of them took part in lipid lowering treatment at their hospital discharge. Comparing these results with international experiences we found that the application of ACE-inhibitors was higher, while that of $\beta$-receptor-blockers was lower than the international average. Studying our practice two years later the results showed that significant improvement occurred in administration of beta-blockers, slight increase in the antiplatelet and in lipid lowering treatment, with no change in the use of ACE-inhibitors. Considering the published international and Hungarian data, in our practice the application of aspirin was very high, above $90 \%$. The administration of ACE-inhibitors in our department, in accordance with other Hungarian studies, is higher, than the international average. However there's a lag in using lipid lowering drugs but according to our data, improvement in this regard is expected, as well. Probably in a few years this kind of lipid lowering treatment, i.e. the application rate of statins, will increase due to the ever growing evidences on event reduction and the more advantageous financial conditions. In addition, more importance will be set on achieving the target lipid levels $(5,28)$, which, in accordance with results of the newest studies, will be, probably, even lower (29).

In our study half year after AMI the drug review showed that administration of aspirin decreased (because of side effects, this is why new antiplatelet drugs should be used) no change occurred in the rate of ACE-inhibitor use and it was favourable, that more patients received beta-blocker treatment than at their hospital discharge.

Our data are comparable with international ones, in some cases our results are more favourable (ACE-inhibitors), but still significant reserves are available in the treatment of patients after AMI. Beside strict control and continuous education of patients the periodical review and check of the quality of our work are also necessary. According to our data the application rate of $\beta$-blockers increased by $48 \%$ between the 1999-2000 and the 2002 survey. The practical application of the ever growing principles of the evidence based medicine means a hard task for the physicians, which on a proper level - we believe - only with continuous self-control can be accomplished.

\section{REFERENCES}

1. Józan P. New trends in mortality and life expectancy: epidemiologic transition in Hungary? Orv Hetil. 2003 Mar 9;144(10):451-60. (In Hungarian.)

2. Máchová L, Janout V. The incidence of acute myocardial infarction in the district Olomouc in 1994 - descriptive study. Cent Eur J Public Health. 1997 Sep;5(3):122-6.

3. Komárek L, Rážová J, Pivničková M, Vignerová J, Roth Z, Ošancová K, Šoltysová T, Anděl M, Poledne R. Indicators of risk of ischaemic heart disease in patients with acute myocardial infarction under 65 years and their relatives. Cent Eur J Public Health. 1998 Aug;6(3):202-10. 
4. Rosamond WD, Chambless LE, Folsom AR, Cooper LS, Conwill DE, Clegg L, Wang CH, Heiss G. Trends in the incidence of myocardial infarction in mortality due to coronary heart disease, 1987 to 1994. N Engl J Med. 1998 Sep 24;339(13):861-7.

5. De Backer G, Ambrosioni E, Borch-Johnsen K, Brotons C, Cifkova R, Dallongeville J. Ebrahim S, Faergeman O, Graham I, Mancia G, Manger Cats V, Orth-Gomer K, Perk J, Pyorala K, Rodicio JL, Sans S, Sansoy V, Setchem U, Silber S, Thomsen T, Wood D; Third Joint Task Force of European and Other Societies on Cardiovascular Disease Prevention in Clinical Practice. European guidelines on cardiovascular disease prevention in clinical practice. Eur Heart J. 2003 Sep;24(17):1601-10.

6. Baigent C, Collins R, Appleby P, Parish S, Sleight P, Peto R; ISIS-2 Collaborative Group. ISIS-2: 10 year survival among patients with suspected acute myocardial infarction in randomised comparison of intravenous streptokinase, oral aspirin, both, or neither. BMJ. 1998 May 2;316(7141):1337-43.

7. Antithrombotic Trialist's Collaboration. Collaborative meta-analysis of randomized trials of antiplatelet therapy for prevention or death, myocardial infarction, and stroke in high risk patients. BMJ. 2002 Jan 12;324(7329):71-86.

8. Teo KK, Yusuf S, Furberg CD. Effects of prophylactic antiarrhythmic drug therapy in acute myocardial infarction. An overview of results from randomized controlled trials. JAMA. 1993 Oct 6;270(13):1589-95.

9. ISIS-1 Collaborative Group. Randomised trial of intravenous atenolol among 16027 cases of suspected acute myocardial infarction: ISIS-1. Lancet. 1986 Jul 12;2(8498):57-66.

10. The MIAMI Trial Research Group. Metoprolol in acute myocardial infarction (MIAMI). A randomised placebo-controlled international trial. Eur Heart J. 1985 Mar;6(3):199-226.

11. ISIS 4 Collaborative Group. ISIS-4: a randomised factorial trial assessing early oral captopril, oral mononitrate, and intravenous magnesium sulphate in 58,050 patients with suspected acute myocardial infarction. Lancet. 1995 Mar 18;345(8951):669-85.

12. The Acute Infarction Ramipril Efficacy (AIRE) Study Investigators. Effect of ramipril on mortality and morbidity of survivors of acute myocardial infarction with clinical evidence of heart failure. Lancet. 1993 Oct 2;342(8875):821-8

13. Pfeffer MA, Braunwald E, Moye LA, Basta L, Brown EJ Jr, Cuddy TE, Davis BR, Geltman EM, Goldman S, Flaker GC; The SAVE Investigators. Effect of captopril on mortality and morbidity in patients with left ventricular dysfunction after myocardial infarction. Results of the survival ventricular enlargement trial. N Engl J Med. 1992 Sep 3;327(10):669-77.

14. Smith SC, Blair SN, Bonow RO, Brass LM, Cerqueira MD, Dracup K, Fuster V, Gotto A, Grundy SM, Miller NH, Jacobs A, Jones D, Kruss RM, Mosca L, Ockene I, Pasternak RC, Pearson T, Pfeffer MA, Starke RD, Taubert KA. AHA/ACC Guidelines for Preventing Heart Attack and Death in Patients With Atherosclerotic Cardiovascular Disease: 2001 update. A statement for healthcare professionals from the American Heart Association and the American College of Cardiology. J Am Coll Cardiol. 2001 Nov 1;38(5):1581-3.

15. Scandinavian Simvastatin Survival Study Group. Randomized trial of cholesterol lowering in 4444 patients with coronary heart disease: the Scandinavian Simvastatin Survival Study (4S). Lancet. 1994 Nov 19;344(8934):1383-9.

16. Sacks FM, Pfeffer MA, Moye LA, Rouleau JL, Rutherford JD, Cole TG, Brown L, Warnica JW, Arnold JM, Wun CC, Davis BR, Braunwald E; Cholesterol and Recurrent Events Trial Investigators. The effect of pravastatin on coronary events after myocardial infarction in patients with average cholesterol levels. N Engl J Med. 1996 Oct 3;335(14):1001-9.

17. The Long-Term Intervention with Pravastatin in Ischaemic Disease (LIPID) Study Group. Prevention of cardiovascular events and death with pravastatin in patients with coronary heart disease and a broad range of initial cholesterol levels. N Engl J Med. 1998 Nov 5; 339(19):1349-57.

18. Athyros VG, Papageorgiou AA, Mercouris BR, Athyrou VV, Symeonidis AN, Basayannis EO, Demitriadis DS, Kontopoulos AG. Treatment with atorvastatin to the National Cholesterol Educational Program goal versus 'usual' care in secondary coronary heart disease prevention. The GREek Atorvastatin and Coronary-heart-disease Evaluation (GREACE) study. Curr Med Res Opin. 2002;18(4):220-8

19. Fonarow GC, Gawlinski A, Moughrabi S, Tillisch JH. Improved treatmen of coronary heart disease by implementation of a Cardiac Hospitalization Atherosclerosis Management Program (CHAMP). Am J Cardiol. 2001 Apr $1 ; 87(7): 819-22$.

20. EUROASPIRE Study Group. A European Society of Cardiology survey of secondary prevention of coronary heart disease: principal results. Eur Heart J. 1997 Oct;18(10):1569-82.

21. EUROASPIRE II Study Group. Lifestyle and risk factor management and use of drug therapies in coronary patients from 15 countries: principal results from EUROASPIRE II Euro Heart Survey Programme. Eur Heart J. 2001 Apr;22(7):554-72.

22. Östör E, Jánosi A, Ádám Z, Bárczy Gy, Borbás S, Dávid B, Gallai I, Podmaniczky M, Ruzsányi T. Secondary prevention of coronary disease - at the turn of the millennium in light of the Hungarian data of the EUROASPIRE I-II Studies. Orv Hetil. 2003 Dec 7; 144(49):2399-404. (In Hungarian.)

23. Hasdai D, Behar S, Walletin L, Danchin N, Gitt E, Boerjma E, Fioretti PM, Simons ML, Battler A. A prospective survey of the characteristics, treatments and outcomes of patients with acute coronary syndromes in Europe and the Mediterranean basin. The Euro Heart Survey of Acute Coronary Syndromes. Eur Heart J. 2002 Aug;23(15):1190-201.

24. Zöllei É, Paprika D, Vincze D, Rudas L. Quality assessment in the management of acute coronary syndromes. Lege Art Med. 2002;12 (8):488-92. (In Hungarian.)

25. Vale MJ, Jelinek MV, Best JD, Santamaria JD. Coaching patients with coronary heart disease to achieve target cholesterol: a method to bridge the gap between evidence-based medicine and the ,real world" - randomised controlled trial. J Clin Epidemiol. 2002 Mar;55(3):245-52.

26. EUROASPIRE I and II Group. Clinical reality of coronary prevention guidelines: a comparison of EUROASPIRE I and II in nine countries. Lancet. 2001 Mar 31;357(9261):995-1001.

27. Pearson TA, Laurora I, Chu H, Kafonek S. The lipid treatment assesment project (L-TAP): a multicenter survey to evaluate the percentages of dyslipidemic patients receiving lipid-lowering therapy and achieving low-density lipoprotein cholesterol goals. Arch Intern Med. 2000 Feb 28;160(4):459-67.

28. Expert Panel on Detection, Evaluation, and Treatment of High Blood Cholesterol in Adults. Executive Summary of The Third Report of The National Cholesterol Education Program (NCEP) Expert Panel on Detection, Evaluation, and Treatment of High Blood Cholesterol In Adults (Adult Treatment Panel III). JAMA. 2001 May 16;285(19):2486-97.

29. Cannon CP, Braunwald E, McCabe CH, Rader DJ, Rouleau JL, Belder R, Royal SV, Hill KA, Pfeffer MA, Skene AM; Pravastatin or Atorvastatin Evaluation and Infection Therapy-Thrombolysis in Myocardial Infarction 22 Investigators. Intensive versus moderate lipid lowering with statins after acute coronary syndromes. N Engl J Med. 2004 Apr 8;350(15):1495-1504.

Received May 30, 2005

Received in revised form and accepted

December 2, 2005 